Canadian University Music Review

Revue de musique des universités canadiennes

\title{
Timothy L. Jackson and Paul Hawkshaw, eds. Bruckner Studies. Cambridge: Cambridge University Press, 1997. xvi, 301 pp. ISBN 0-521-57014-X (hardcover)
}

\section{Zoltan Roman}

Volume 19, numéro 1, 1998

URI : https://id.erudit.org/iderudit/1014613ar

DOI : https://doi.org/10.7202/1014613ar

Aller au sommaire du numéro

Éditeur(s)

Canadian University Music Society / Société de musique des universités canadiennes

ISSN

0710-0353 (imprimé)

2291-2436 (numérique)

Découvrir la revue

Citer ce compte rendu

Roman, Z. (1998). Compte rendu de [Timothy L. Jackson and Paul Hawkshaw, eds. Bruckner Studies. Cambridge: Cambridge University Press, 1997. xvi, 301 pp. ISBN 0-521-57014-X (hardcover)]. Canadian University Music Review / Revue de musique des universités canadiennes, 19(1), 99-104. https://doi.org/10.7202/1014613ar

All Rights Reserved (C) Canadian University Music Society / Société de musique des universités canadiennes, 1998
Ce document est protégé par la loi sur le droit d'auteur. L’utilisation des services d'Érudit (y compris la reproduction) est assujettie à sa politique d'utilisation que vous pouvez consulter en ligne.

https://apropos.erudit.org/fr/usagers/politique-dutilisation/ 
interest. This chapter, like all the others, is replete with intensive detail reported in an eminently readable style.

Although Mongrédien's study lacks much discussion or analysis of actual music, I do not feel that this is a serious problem. In part at least, his intent was surely to provide the basis for further investigation into the material his scholarly researches have uncovered. I would, however, raise three small quibbles. First, as is often the case with works about French music, what this book deals with is, almost exclusively, the music of Paris, not the music of France (though part of the chapter on opera deals with Lyon). Second, Mongrédien's title is slightly misleading. He does not address the music of the Enlightenment at all, except when discussing Lacépède. His book really evaluates the history of Parisian music from the fall of the Bastille to 1830 . Third, the dates given in the French Revolutionary calendar (pp. 347-48) do not accord with those published in the Encyclopaedia Britannica, particularly with respect to the jours sans-culottides, to which part-month Mongrédien ascribes only four days, the $E B$ anywhere between fourteen and eighteen, depending on the year. These small points aside, French Music from the Enlightenment to Romanticism is a fundamental and most welcome addition to musical scholarship.

Alison Stonehouse

Timothy L. Jackson and Paul Hawkshaw, eds. Bruckner Studies. Cambridge: Cambridge University Press, 1997. xvi, 301 pp. ISBN 0-521-57014-X (hardcover).

Although the period between 1860 and the First World War had its fair share of "controversial" composers, the subject of the present volume appears-at least in retrospect-to have outdone them all. Not only did Anton Bruckner (1824-96) suffer a lifetime of hostility, neglect, and misunderstanding (Gustav Mahler, his great successor in the Austrian musical firmament, did not fare much better, after all), his posthumous reputation has been subject to vicissitude and factionalism. Moreover, the ebb and flow of professional and popular opinion has been driven by what is all too often an unstable, capricious mix of musical and non-musical considerations. Whether it is the temporal and sonic abundance of Bruckner's symphonies, his aggrandizement as a cult-figure by National Socialism, or any one of a number of other (real or imagined) "problems," positions taken for or against virtually any question about the man and his music have been defended vigorously (often to the point of disregard for the niceties of rational and dispassionate argument) by adherents of a wide variety of national and geographic "camps."

It will not surprise the student of modern Rezeptionsgeschichte that the most stubborn and - even if only through indifference-broadest resistance to Bruckner has been based in North America. Although negligible shifts in sentiment have occurred even here, an earlier, substantial improvement in the composer's 
European fortunes is now having a decisive impact in the New World. In some important ways, the collection of essays before us reflects that change, with all its benefits and problems. Containing eleven studies originally presented at the first international Bruckner symposium held in North America, ${ }^{1}$ this volume is represented as "the most important English-language book on the composer since Robert Simpson's The Essence of Bruckner" (1967). Further, it claims to challenge the reader "to reassess the man and his music in a new light, unencumbered by decades of special interest and propaganda which have colored perceptions of Bruckner for more than a century" (p. [i]).

It would be almost unreasonable to expect a collection of essays, necessarily disparate in style, focus and-yes-"agenda," to live up to such billing, even when read with good will and sympathy for its subject. This collection is no exception, for a number of reasons. Perhaps predictably, chief among them is its failure to satisfy the implied claim of freedom from "special interest and propaganda." To be sure, such biases differ here from other, historical ones, but their effect is, in some ways, nearly as prejudicial to the attaining of a clear and balanced understanding of the man and his music. The seven "historical studies" display a pervasive inability (or is it unwillingness?) to consider the plausibility of earlier views and approaches in their contemporary context (as faulty or disreputable - even repugnant-as some of them may appear to us today). The goals and potential impact of the four "analytical studies" (comprising more than half of the volume) are often obscured and impeded by a dense (and, at times, injudicious) use of the jargon of "new" theory (which is, in truth, rarely more than a "tweaked" application of older concepts and practices, chief among them Schenkerism).

Limitations of space preclude an equally detailed discussion of each essay, but similarities in topic or method facilitate their grouping. (Admittedly, such an approach may make it a bit more difficult to keep out the prejudices of a conservative academic.)

\section{Historical STUdIES}

Appropriately enough, the "historical" section of the collection opens with Paul Hawkshaw's painstaking-if necessarily synoptic-text-critical demonstration of a problem which, perhaps more than any other, bedevilled Bruckner's music during his lifetime and long after. ${ }^{2}$ In "An Anatomy of Change: Anton Bruckner's Revisions to the Mass in F Minor" (pp. 1-31), the author traces many of the more or less important changes to which this work had been subjected by later editors, "disciples," and the composer himself, following its "completion" in 1868 . The extent of the problem is illustrated by the fact that, because of the untrammelled, if well-intentioned, interventions of one of the

1 Perspectives on Anton Bruckner: Composer, Theorist, Teacher, Performer, 21-24 February 1994, Connecticut College, New London, Conn.

2The full scholarly apparatus pertaining to this work will appear in vol. XVIII of Bruckner: Sämtliche Werke B (p. 2 n. 5). 
chief "disciples," Josef Schalk, the first edition of the Mass (1894) is no more than an "arrangement," with little value as a source (pp. 30-31).

Hawkshaw's essay forms an interesting pair with one by Benjamin Marcus Korstvedt, "'Return to the Pure Sources': The Ideology and Text-critical Legacy of the First Bruckner Gesamtausgabe" (pp. 91-109). The former focusses on source-critical questions relating to a single work; it is overwhelmingly positivist in approach, leaving this reader impressed, if somewhat ennuyé. Korstvedt's piece, on the other hand, tackles the problem of the first collected edition (Bruckner: Sämtliche Werke A, [1930-53]), one whose editorial policies inevitably came under the sway of National Socialism. Thus, this author uses history and historiography to illuminate a subject the interest of which extends beyond the chronological limits of the present essay. But for a tendency to view all aspects of the "legacy" in unrelieved black and white and a seemingly uncritical resolve to import into musical text-editing the tenets and practices of literary criticism, this is an engaging and important study.

For three of the historical studies in this volume, the focus is Bayreuth-that is to say, the Master, living, dead, and deified. Margaret Notley ("Bruckner and Viennese Wagnerism" [pp. 54-71]) emphasizes-perhaps a bit too stronglythe connections between the ascendancy of Wagner and Bruckner and the political shift to the right that was taking place in Austria at the turn of the century. Although this essay sheds some new light on the relations, motives, and conduct of some of the principal characters, its impact is impaired by evidence of superficial research. For example, why refer the reader to a book on Mahler by Henry-Louis de La Grange for "additional information" on Theodor Helm? [p. 64 n. 45]. Bryan Gilliam's "The Annexation of Anton Bruckner: Nazi Revisionism and the Politics of Appropriation" (pp. 72-90) moves the scene to a larger stage. It gives an absorbing, thorough account of the Nazis' "reinvention" of the composer, something which flowed directly from their politicizing of Wagner and Bayreuth. But Bruckner's status as a National Socialist icon also served them in such social and political spheres as relations with the Vatican. Unfortunately, by failing to stop at the chronological limit suggested by the topic itself (that is, 1945), this otherwise valuable musico-political study dissolves in a perfunctory and confused attempt to deal with the "postwar consequences" of the Nazis' "appropriation" of Bruckner ("Or is this properly a misappropriation?" [p. 87]) and ends with a somewhat embarrassing "call-for-action": "Bruckner research cannot move forward without confronting its past, especially the dark chapter of Bruckner reception during the Third Reich" (p. 90).

The last essay in this "Bayreuth" group is Stephen McClatchie's "Bruckner and the Bayreuthians; or, Das Geheimnis der Form bei Anton Bruckner" (pp. 110-21). It is a courageous-if not entirely satisfying - foray into the minefield of Wagner's cultural and political writings and their influence on, and exploitation by, right-leaning (or merely opportunist) musicians, writers, and politicians. Bruckner's gradual absorption into the musico-political maelstrom that was National Socialist Bayreuth was carefully crafted by Alfred Lorenz 
and his disciples, Karl and Hans Alfred Grunsky. Although part of the essay gives a fine account of this process, the whole suffers from a lack of focus on the central subject of Bruckner. This may well be due to the fact that-as the author himself concludes-"the intersection of National Socialist ideology, Lorenzian formal analysis, and Bruckner ... is not unique" for "a similar paper could be written about Liszt or Strauss" (p. 121).

The remaining two "historical studies" are not readily grouped (or even classified in the context of the volume as a whole) and represent the weakest contributions here. For "A Hidden Personality: Access to an 'Inner Biography' of Anton Bruckner" (pp. 32-53), Elisabeth Maier rummaged through the composer's sadly inarticulate and unrevealing "pocket" calendars-those, that is, that are extant and accessible (little more than half of the putative total). These are not diaries in a meaningful and potentially fruitful sense and (pace the author [p. 35]) provide far less genuine insight into Bruckner's personality than does even his-admittedly meagre-correspondence. Aside from a quasivoyeuristic fascination with Bruckner at prayer, morning, noon, and night, the labour of reading this essay is wholly incommensurate with any enlightenment one may gain from it.

Robert W. Wason's "Josef Schalk and the Theory of Harmony at the End of the Nineteenth Century" (pp. 122-39) is a study of an incomplete, unpublished theoretical treatise. Here, it gains even passing interest only if we accept the author's claim that Schalk was undertaking the "creative extension and modification of the theory Bruckner had taught him" (p. 122). Otherwise, the thickets of technical jargon (pitch classes, subsets, commas, lemmas, and the like)-virtually impenetrable at times-could appeal only to (pure) theorists and acousticians. Or-to quote one of Wason's musings slightly out of context- "in the end, we are left wondering whether this is all theory, or whether it has some relationship to musical practice" (p. 134).

(To do some musing of my own: in the case of "proceedings"-even if they are not so labelled-should the critic question the contents, given the known fact that the originals had been accepted [or invited] for a conference? On the other hand, should editors escape all responsibility for what they include [or not] in such a publication?)

\section{ANALYTICAL STUDiES}

The four analytical studies in this volume fall into two groups. Putting it simply, two essays deal with questions of sonata form in Bruckner's music, while the others examine some of its harmonic and rhythmic procedures.

Timothy L. Jackson's “The Finale of Bruckner's Seventh Symphony and the Tragic Reversed Sonata Form" (pp. 140-208) is, in more than one respect, an astonishing piece of writing. Immediately jarring is the study's first substantive statement: "Since Bruckner synthesized classical with 'New German' influences, the semantic content of his music may be decoded with reference to both classical and avant-garde traditions" (p. 140). Reading this together with the author's argument, unfolded in the essay's "coda space," that Mahler 
came under Bruckner's musical influence increasingly in his later works (pp. 199-201), makes one wonder whether the study can succeed in spite of this artificial misframing (or should that be 'tragic reversal'?) of the musical-stylistic continuum. That it does so, by and large, is due partly to the fact that this "framing" gambit proves to have very little to do with its substance, and partly to the impressive-if not always convincing-historical exploration of the problem. For the reader, surprised at first by the study's monographic size, soon realizes that the title's reference to one movement of one cyclic work is, essentially, misleading. In fact, the study ranges from Aristotle and Greek dramatic and linguistic rhetorical theory, through Schenker and Salzer, to Rosen, Hepokoski, and Tarasti, and from Haydn, Mozart, and Beethoven to Bruckner, Mahler, and Sibelius, all in order to prove the existence of a "tragic reversed sonata form." 3 In the pursuit of this goal, theorist forerunners are chided for failing to observe it in their studies of earlier music. Thus, Charles Rosen is taken to task for noting reversed recapitulation "only in passing, without mentioning its possible tragic significance" in his Sonata Forms (p. 143 n. 3), while Heinrich Schenker and Ernst Oster are censured for the "gaps" in their account of sonata form (pp. 149-50). The bulk of the discussion devoted to the Symphony named in the title (pp. 194-99) concerns the musical allusions to Beethoven, Wagner, and Liszt that were discovered by Jackson in the work-and which, "astonishingly," have received nary a mention in the literature (p. 196 n. 90).

Although it also figures in the preceding piece, readers less than fluently conversant with James Hepokoski's attractive (at least for its post-positivist spirit) and potentially useful "sonata deformation" theory will find a betterchiefly because more focused-account of it in Warren Darcy's "Bruckner's Sonata Deformations" (pp. 256-77). Still, the apparent need to tilt at the windmill of "a narrow, prescriptive view of sonata form, derived largely from nineteenth-century Formenlehre paradigms" (p. 256) burdens this essay as well. The so often needlessly jargonistic prose of this type of analytical approach is also ever-present. And so we get an "alienated secondary theme zone" (read: the exposition of a secondary theme in an unexpected key); if this transgression against the Formenlehre model recurs in the recapitulation, we are faced with an out-and-out "sonata process failure."

Edward Laufer's "Some Aspects of Prolongation Procedures in the Ninth Symphony (Scherzo and Adagio)" (pp. 209-55) provides us with an instructive and entertaining example of the discomforts willingly assumed by Schenkerian Brucknerites in an effort to avoid criticizing either one, however objectively. Thus, finding "ambiguity" (something that was anathema to Schenker) in the development section of the Adagio leads the author to this daring-if very much intermediate—statement: "Schenker's criticisms [of Bruckner's music]

3 The term merges the altered ordering of groups in a recapitulation with Aristotle's peripety that is said to arise from the attendant "incorrect" tonal order. The potential flaw of this argumentation lies, of course, in its necessary insistence on the reality of a "normative" sonata form. 
do not stand up to [today's] Schenkerian criticism" (p. 249). But all's well that ends well: after a highly circuitous route through numerous complex analytical graphs, Laufer reaches-with well-nigh palpable relief - the only desirable conclusion: however it may strike us, and despite anything he himself may have told his pupils, Bruckner did, in fact, compose in a manner which satisfies "Schenker's concept of the organic nature of a great work of art" (p. 255).

These proceedings conclude with Joseph C. Kraus's refreshingly brief "Phrase Rhythm in Bruckner's Early Orchestral Scherzi" (pp. 278-97), a study based on analytical principles and techniques introduced in the 1970s and 1980s by Carl Schachter and William Rothstein. Though ideas of the "normative" (such as achttaktige Periode) crop up here, too, this piece steers clear of the shoals of l'analyse pour l'analyse; accordingly, it manages to impart to the reader a genuine sense of the living music. And in today's world of leadingedge music analysis, that is not a small accomplishment.

In their Preface, the editors write: "When Anton Bruckner died in October 1896, the musical world lost a composer, theorist, teacher, and performer who stood at the cutting edge of the avant-garde of his generation" (p. xi). Such a statement would have been dismissed as hyperbole just twenty years ago. Although not free of its own kinds of excess, this book, as a whole, illuminates well the road that has brought us to recognizing such a pronouncement as worthy of serious contemplation. Aside from a few minor captioning and typographical problems, the volume is beautifully produced and richly illustrated with photographs, facsimiles, tables, and analytical graphs.

Zoltan Roman

Guy Sacre. La musique de piano : dictionnaire des compositeurs et des cuvres. Collection «Bouquins ». Paris : Éditions Robert Laffont, 1998. 2 vol. xxxviii (vol. 1, A-I), xxvi (vol. 2, J-Z), 2998 p. ISBN 2-221-05017-7, 2-221-08566-3 (couverture cartonnée).

Les musiciens connaissent les Éditions Robert Laffont pour quelques ouvrages de référence volumineux, dans plusieurs cas des traductions, comme celles du Baker's Biographical Dictionary of Musicians, du New Oxford Companion to Music et du New Kobbé's Complete Opera Book. Leur plus récent titre est un ouvrage que l'on pourra considérer, du moins à première vue, comme le pendant français du Handbuch der Klavierliteratur de Klaus Wolters (Zürich : Atlantis Verlag, 1967; $2^{\mathrm{e}}$ éd., 1977) et du Guide to the Pianist's Repertoire de Maurice Hinson (Bloomington : Indiana University Press, 1973; $2^{e}$ éd., 1987). Son auteur, Guy Sacre, que l'éditeur présente comme un compositeur et pianiste qui a exploré pendant 10 ans des milliers de partitions « afin de les rendre intelligibles à la fois pour le spécialiste et pour l'amateur » (notice publicitaire), ne semble pas avoir encore droit à une notice dans les dictionnaires spécialisés. Les quelques mentions du nom dans l'Internet nous révèlent qu'il est né en 1948 et que quelques-unes de ses pièces pour piano (Variations sur 